\title{
The Effects of Melatonin and Endothelin-A Receptor Antagonist BQ-123 in Exposed to Smoke in Rat Renal Tissue
}

\author{
Hasan Erdogan ${ }^{1}$, Fatih Ekici², Huseyin Aslan ${ }^{3}$, Birsen Ozyurt ${ }^{4}$, Filiz Erdogan ${ }^{5}$, Omer Atis $^{6}$
}

${ }^{1}$ Namık Kemal University, Faculty of Medicine, Department of Physiology, Tekirdag

${ }^{2} Y_{1}$ ldırım Beyazıt University, Faculty of Medicine, Department of Physiology, Ankara

${ }^{3}$ Gaziosmanpasa University, Faculty of Medicine, Department of Histology and Embryology, Tokat

${ }^{4}$ Gaziosmanpasa University, Faculty of Medi cine, Department of Anatomy, Tokat

${ }^{5}$ Tekirdag State Hospital, Department of Obstetrics and Gynecology, Tekirdag

${ }^{6}$ Ataturk University, Faculty of Medicine, Department of Medical Biology, Erzurum

Eur J Basic Med Sci 2013;3(1): 1-8

Received: 25-03-2013

Accepted: 03-04-2013

Correspondence (Yazıșma Adresi):

Hasan Erdogan, MD

Department of Physiology Medical Faculty of Namık Kemal University TR-59100,

Tekirdag, TURKEY

Tel: +902822505502

Fax: +902822509928

Email: haserdogan@yahoo.com

\begin{abstract}
It has been known that smoking increases the level of Endothelin (ET), a very powerful vasoconstrictor agent in circulation, causes damage and functional impairment of tissues. In our study, it was aimed to evaluate the effects of melatonin, a potent antioxidant, and BQ123 on renal tissue of rats exposed to cigarette smoke. Wistar albino 34 adult male rats were divided into four groups; Control, Smoking, Smoking+Melatonin, and Smoking+BQ-123 groups. They were exposed to cigarette smoke in the vacuum-operated glass cabinet 3 times a day, 30 minutes for 28 days. Melatonin was administered i.p. 25 $\mathrm{mg} / \mathrm{kg} /$ every day. BQ-123 was injected from tail vein i.v. $1 \mathrm{mg} / \mathrm{kg}$, on the first, 7th, 14th, 21th, 27th day. After the rats were sacrificed on the 28th day, the biochemical parameters were analyzed with spectrophotometric methods and tubular cell accounts for stereological analysis were done by optical fractionator technique. Renal tissue SOD activity was significantly increased in the Smoking+Melatonin group according to the control and Smoking+BQ-123 groups. Catalase activity was significantly decreased in the Smoking+Melatonin according to the other groups. Lipid peroxidation level was significantly increased in Smoking group in comparison with the Control and Smoking+BQ-123 groups. Protein Carbonyl and Nitric Oxide levels, and GSH-Px activity have not statically significant among the groups. Tubular cell accounts were significantly increased in the given of Melatonin and $B Q-123$ groups according to the Control and Smoking groups. We concluded that cellular damage generated by smoke in renal tissue of rats partially reduced by Melatonin and BQ-123 depending on the dose and duration with different pathways. This conclusion was supported by histologic staining and stereologic analysis with increase of the cell number of renal tissue in rats.
\end{abstract}

Key Words: Smoking, Melatonin, BQ-123, Endothelin receptor antagonist

Sigaraya Maruz Kalmış Sıçan Böbrek Dokusunda Melatonin ve Endotelin Reseptör Antagonisti BQ-123'ün Etkisi

\section{ÖZET}

Sigaranın dolașımda çok güçlü bir vazokonstriktör ajan olan endotelin (ET) düzeyini artırdığı, doku hasarına ve fonksiyonunda bozulmaya yol açtığı bilinmektedir. Çalışmamızda, sigaraya maruz bırakılan sıçanların böbrek dokusunda, güçlü antioksidan melatonin ve ET reseptör antagonisti BQ-123'ün etkilerinin değerlendirilmesi amaçlandı. Erișkin erkek 34 Wistar Albino sıçan Kontrol, Sigara, Sigara+Melatonin, Sigara+BQ-123 olmak üzere 4 gruba ayrıldı. Günde 3 kez, 30 dakika, 28 gün süreyle cam kabin içinde vakumlayarak si- 
garaya maruz birakıldılar. Melatonin her gün $25 \mathrm{mg} / \mathrm{kg}$ dozda i.p., $B Q-123$ ise $0,7,14,21,27$. günlerde kuyruk veninden $1 \mathrm{mg} / \mathrm{kg}$ dozunda verildi. Biyokimyasal parametreler spektrofotometrik yöntemle, tübüler hücre sayımları stereolojik metotlardan optik fraksiyonlama yöntemiyle değerlendirilmek üzere 28. günde sıçanlar sakrifiye edildi. Renal doku süperoksit dismutaz (SOD) aktivitesi Sigara+Melatonin grubunda, Kontrol ve Sigara+BQ-123 gruplarına göre anlamlı olarak arttı. Katalaz aktivitesi ise Kontrol, Sigara, Sigara+BQ-123 gruplarına göre Sigara+Melatonin grubunda anlamlı olarak azaldığı görüldü. Lipit peroksidasyon düzeyi, Sigara grubunda Kontrol ve Sigara+BQ-123 grubuna göre anlamlı olarak arttığı bulun$d u$. Protein karbonil ve nitrik oksit düzeyleri ile glutatyon peroksidaz (GSH-Px) aktivitesinde istatistiksel olarak anlaml bir farklılık görülmedi. Tübüler hücre sayıları BQ-123 ve Melatonin verilen gruplarda Kontrol ve Sigara gruplarına göre anlamlı olarak arttığı görüldü. Sigaranın böbrek dokusunda olușturduğu hücresel hasarı, Melatonin ve BQ-123'ün değişik yolaklarla doz ve süreye bağlı azalttığı düşünüldü.

Anahtar kelimeler: Sigara içme, Melatonin, BQ-123, Endotelin reseptör antagonisti

\section{INTRODUCTION}

Smoking which is a common habit among people are known to increase a lot of diseases related to respiratory system, testis, brain, heart, blood vessels, skin, kidney. Due to the risk of becoming and causing diseases, smoking leads to important health problems. It is located in the etiology of many diseases, for example, the inflammation of stomach and duodenum structures, chronic obstructive pulmonary disease (COPD), atherosclerosis, cancers, peptic ulcer disease, renal cell carcinoma (1).

Melatonin is endogenously secreted by the pineal gland, well-known in the role of circadian rhythm, having a very strong antioxidant activity. Receptor mediated effects stimulates the expression of intracellular antioxidant and detoxification genes via signal transduction (2). Melatonin has also strong reactive oxygen species (ROS) scavenging effect. Thus, it has a powerful protective effect against free radical damage cells and tissues $(2,3)$. Direct and indirect effects of cigarette smoke on important oxidative evidence were obtained in scientific studies $(4,5)$. Research was presented that people who cigarette smoke have either increase (6) or decrease (5) in circulating melatonin levels.

Endothelin (ET) a potent vasoconstrictor and mitogen agent involved in the regulation of vascular tone $(7,8)$. The main type of ET is Endothelin-1 (ET-1) in human plasma $(9,10)$. Discovered by Yanagisawa (11), ET has two types receptor in cell membranes. ETA receptors (ETAR) are primarily found on the vascular smooth muscle cell membrane. ET-1 via ETAR leads to vasoconstriction, mitogenesis, and anti-apoptotic effect with increased intracellular $\mathrm{Ca}+2$ concentrations. ETB receptors (ETBR) are mainly found on the endothelial cell membrane. ET-1 via ETBR causes ET-1 clearance, cell death and vasodilation with nitric oxide (NO) and prostosiclin (PGI2) secretion $(7,10,12)$. BQ-123 was firstly synthesis as ETAR antagonist (13), has antioxidant effects, and has protective effect from renal ischemia and reperfusion (14). ET-1 increases within ten minute following cigarette smoking in plasma $(15,16)$. It might be associated with the harmful effects of smoking such as atherosclerosis (15), essential hypertension (17), cardiovascular pathophysiology (18), renal dysfunction (19).

In that case, the damage of smoking might be improved by the treatment of Melatonin and ETAR antagonist. Our scans of the literature, the effects of melatonin and ET receptor antagonists against damage caused by cigarette smoking were not investigated in especially renal tissue. Therefore, we aimed of the current study was to determine that the rats exposed to cigarette smoke in renal tissue of rats were comparatively assessed the effects of melatonin as one of the most powerful antioxidant substances and BQ-123 as an ETAR antagonist.

\section{MATERIAL and METHODS}

\section{Animals and animal treatments}

Thirty-four Wistar albino adult male rats weighing 220-300g were used in the experimentations. The experiments were performed in accordance with "The National Institute of Health Guide for the Care and Use of Laboratory Animals (NIH Publications No. 80-23) (Revised 1996)." The experiments were approved by the local ethical committee of the Medical School of Gaziosmanpasa University. All experiments were carried out in the laboratories at Gaziosmanpasa University. The rats were randomly assigned to three groups: Control group ( $n=10)$, Smoking group ( $n=9)$, Smoking+Melatonin group $(n=5)$, and Smoking+BQ-123 group $(n=10)$. They were exposed to smoking in the vacuum-operated glass cabinet $(0.5 \times 0.5 \times 1 \mathrm{~m}) 3$ times a day, 30 minutes for 28 days. Rats exposed to three cigarette smoke in thirty minutes. Melatonin was administered i.p. $25 \mathrm{mg} / \mathrm{kg} /$ day. BQ-123 was injected from tail vein i.v. $1 \mathrm{mg} / \mathrm{kg}$, on the first, 7th, 14th, 21th, 27th day. Rats were sacrificed on the 28th day under i.p. $30 \mathrm{mg} / \mathrm{kg}$ ketamine and 5 
$\mathrm{mg} / \mathrm{kg}$ xylazine anesthesia. Right kidney was removed with surgical technique for the analysis of biochemical parameters by spectrophotometric method, stored at -80 0C until enzymatic analysis. Homogenate, supernatant, and extracted samples (20) from the kidney were prepared for the antioxidant enzyme analysis of superoxide dismutase (SOD), catalase (CAT), glutathione peroxidase (GSH-Px), and the levels of nitric oxide (NO), thiobarbituric acid reactive substance (TBARS), protein carbonyl (PC), protein (with Lowry's method) (21).

\section{Renal Tissue Nitric Oxide (NO) Levels}

The index parameters of NO, nitrite and nitrate levels, were measured by Griess reaction (22). The spectrophotometric analysis of NO was calculated by a standard curve, prepared with a set of serial dilutions of sodium nitrite.

\section{Renal Tissue Superoxide Dismutase (SOD) Activity}

The reduction of nitroblue tetrazolium was used for analysis of SOD activity (EC 1.15.1.1) (23). The SOD activity was measured from ethanol phase of extracted samples with ethanol/chloroform mixture $(5 / 3, v / v)$. The results were given as unit that was defined as the amount of enzyme for $50 \%$ inhibition of nitroblue tetrazolium reduction rate.

\section{Renal Tissue GSH-Px activity}

The GSH-Px activity (EC 1.6.4.2) was analyzed according to alteration of $\mathrm{H} 2 \mathrm{O} 2$ within a mixture of $\mathrm{NADPH}$, reduced glutathione (GSH), sodium azide, and glutathione reductase (24). The activity was measured at $340 \mathrm{~nm}$ by a spectrophotometer.

\section{Renal Tissue Thiobarbituric Acid Reactive Substances (TBARS) Level}

The reaction of thiobarbituric acid with malondialdehyde or malondialdehyde like sbustances is used as index of lipid peroxidation (25). The reaction was done at 90-100 oC and TBARS were measured at $532 \mathrm{~nm}$. We used a standard curve prepared from the experiments of 1,1,3,3-tetramethoxypropane solution with different concentrations in order to calculate the TBARS levels.

\section{Renal Tissue Protein Carbonyl (PC) Content}

The protein oxidation was analyzed by measurement of protein carbonyl (PC). The reaction of carbonyl groups with 2,4-dinitropheniylhydrazine causes the formation of 2,4-dinitropheniylhydrazone. We analyzed the tissue PC level at $360 \mathrm{~nm}$ spectrophotometrically (26).

\section{Histological Examination}

Left kidney was removed for the stereological analysis by optical fractionator technique, immersed in $10 \%$ neutral formalin and post-fixed for 1 week at $4^{\circ} \mathrm{C}$. Renal tissues were washed under running water for 12 hours. After washing, the tissues were embedded in paraffin applied to routine histological procedures. Tissues after it is embedded Rotary microtome (Leica RM 2135, Leica Instruments, Nussloch, Germany) with a $30 \mathrm{~mm}$ thick, systematic random style, thick sections were sampled the rate of $1 / 12$. Additionally, the $5 \mu \mathrm{m}$ thin sections were stained for Periodic Acid Schiff (PAS) stain for histological imaging and composition assessment. A stereology workstation for stereological analysis by optical fractionator technique was used. An unbiased estimation

Table 1.Effects of Melatonin and BQ-123 to renal tubular cell number in the exposed to smoke in rats. Tubular cell numbers were significantly increased in the given of Melatonin and BQ-123 groups according to the Control and Smoking groups. Total volumes significantly increased in Control group according to the other groups.

\begin{tabular}{cllll}
\hline & Tubular Cell Number & Cortical Volume & Medullar Volume & Total Volume \\
\hline 1- Control & $7,920.000 \pm 206.787$ & $20,096.000 \pm 600.388$ & $5,428.400 \pm 195.521$ & $25,524.400 \pm 763.125$ \\
2- Smoking & $8,088.720 \pm 245.245$ & $9,360.000 \pm 294.381$ & $2,804.000 \pm 147.160$ & $12,164.000 \pm 302.218$ \\
3-Smoking+Melatonin & $9,359.520 \pm 255.512$ & $14,664.000 \pm 456.164$ & $4,082.000 \pm 130.591$ & $18,746.000 \pm 511.797$ \\
4- Smoking+BQ-123 & $9,409.400 \pm 213.495$ & $15,782.000 \pm 553.402$ & $4,950.000 \pm 231.582$ & $20,732.000 \pm 650.426$ \\
P & & & & \\
$1 * 2$ & A.D. & 0.001 & 0.001 & 0.001 \\
$1 * 3$ & 0.001 & 0.001 & 0.001 & 0.001 \\
$1 * 4$ & 0.001 & 0.001 & A.D. & 0.001 \\
$2 * 3$ & 0.007 & A.D. & 0.001 & 0.001 \\
$2 * 4$ & 0.004 & 0.001 & 0.001 & 0.001 \\
$3 * 4$ & A.D. & A.D. & 0.017 & A.D. \\
\hline
\end{tabular}




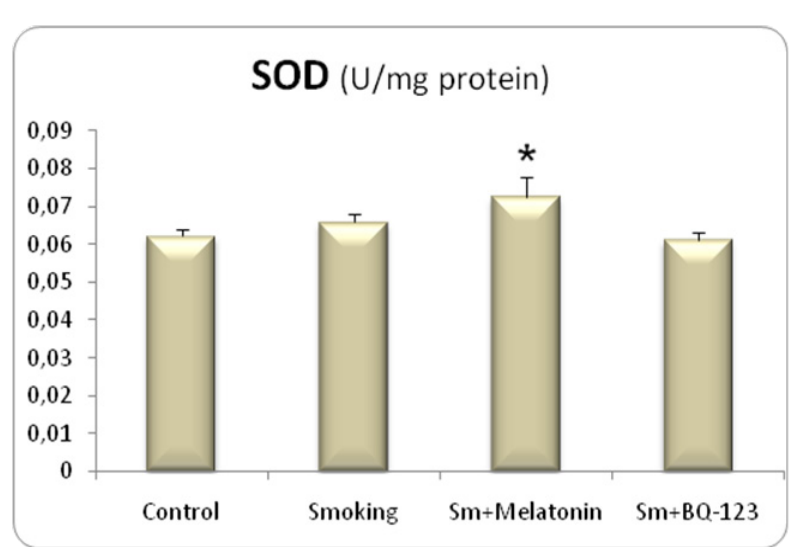

Figure 1. Effects of Melatonin and $B Q-123$ to renal tissue SOD (U/mg protein) activity in the exposed to smoke in rats. Renal tissue SOD activity was significantly increased in the Smoking+Melatonin according to the control $(p<0.014)$ and Smoking $+B Q-123$ $(p<0.008)$ groups.

of the total number of tubular cells from the kidney was obtained by choosing every 12th section, in accordance with the systematic random sampling procedure (27). The stereologic workstation consists of a trinocular microscope (Leica DM 2500; Leica Instruments, Nussloch, Germany), a motorized microscope stage (BioPoint 2; Ludl Electronics, Hawthorne, NY, USA), a digital microcator (Heidenhain; Traunreut, Germany), a color video camera (Q-imaging; Surrey, BC Canada), and personal computer and stereology software (Stereo Investigator;



Figure 3. Effects of Melatonin and BQ-123 to renal tissue GSH-PX (U/g protein) activity in the exposed to smoke in rats. GSH-Px activity has not statically significant difference among the groups.

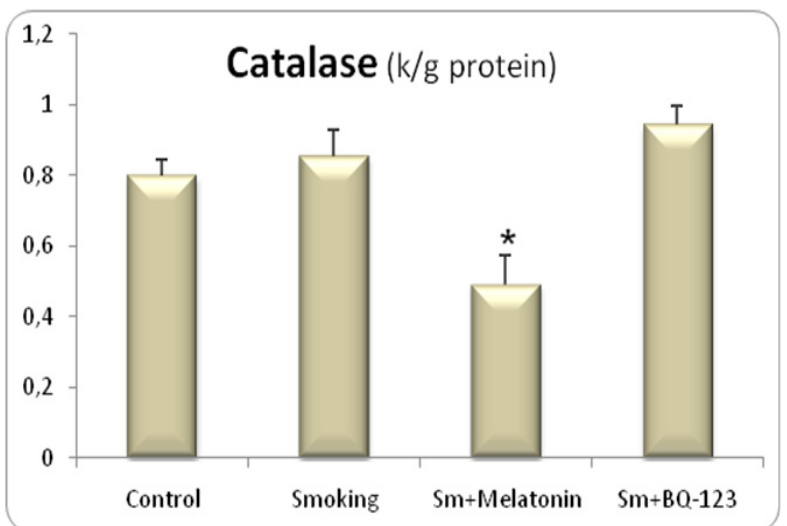

Figure 2. Effects of Melatonin and $B Q-123$ to renal tissue Catalase ( $\mathrm{k} / \mathrm{g}$ protein) activity in the exposed to smoke in rats. Catalase activity was significantly decreased in the Smoking+Melatonin according to Control $(p<0.002)$, Smoking $(p<0.001)$, Smoking $+B Q-123$ $(p<0.001)$.

MBF Biosciences, Williston, VT, USA). Tubular cell numbers were estimated and counted according to the rules of unbiased counting (28-30). Cavalieri's principle was used calculating for total renal cortical and medullar volume (31).

\section{Statistical Analysis}

The one-sample Kolmogorov-Smirnov test was used for analyzing the groups' distribution. The one-way ANOVA test was performed and post hoc multiple compari-

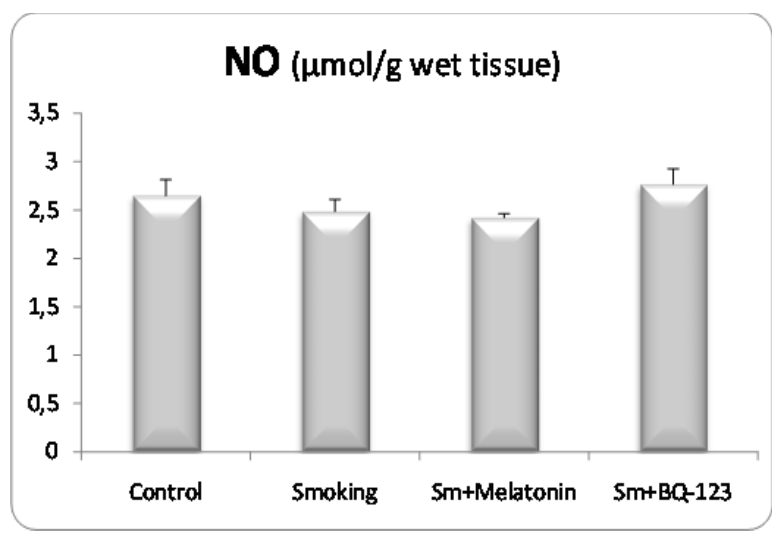

Figure 4. Effects of Melatonin and BQ-123 to renal tissue NO ( $\mu \mathrm{mol} / \mathrm{g}$ wet tissue) levels in the exposed to smoke in rats. NO levels have not statically significant difference among the groups. 


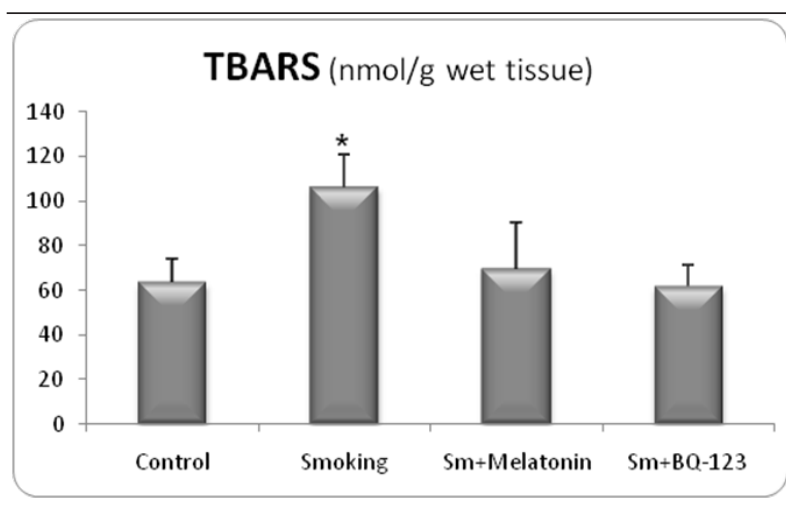

Figure 5. Effects of Melatonin and $B Q-123$ to renal tissue TBARS ( $\mathrm{nmol} / \mathrm{g}$ wet tissue) levels in the exposed to smoke in rats. TBARS level was significantly increased Smoking group according to the Control $(p<0.014)$ and Smoking $+B Q-123(p<0.011)$ group.

sons were done with LSD for the normally distributed groups' variables. All data were analyzed using SPSS for Windows. Results are given as the means \pm standard error of the mean. Level of significance is accepted as p-value $<0.05$.

\section{RESULTS}

Renal tissue SOD activity was significantly increased in the Smoking+Melatonin according to the control and Smoking+BQ-123 groups (Figure 1). Catalase activity was significantly decreased in the Smoking+Melatonin according to Control $(p<0.002)$, Smoking $(p<0.001)$, Smoking+BQ-123 $(p<0.001)$ (Figure 2$)$. GSH-Px activity has not statically significant difference among the groups, although non-significant an increase in Smoking+Melatonin group (Figure 3). Nitric Oxide levels have not statically significantly different among the groups (Figure 4). TBARS level was significantly increased in Smoking group according to the Control $(p<0.014)$ and Smoking+BQ-123 $(p<0.011)$ group, TBARS level of Smoking group has also non-significant an increase according to Smoking+Melatonin group (Figure 5). Protein Carbonyl levels have not statically significantly different among the groups (Figure 6). It was shown that effects of Melatonin and BQ-123 to renal tubular cell number in the exposed to smoke in rats (Table 1). Renal tubular cell numbers were significantly increased in the given of Melatonin and $\mathrm{BQ}-123$ groups according to the Control

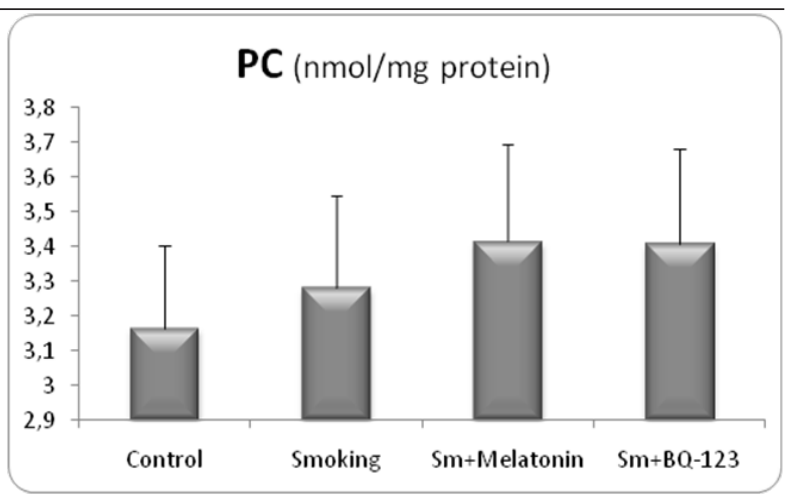

Figure 6. Effects of Melatonin and $B Q-123$ to renal tissue Protein Carbonyl (PC) (nmol/mg protein) levels in the exposed to smoke in rats. $P C$ levels have not statically significant difference among the groups.

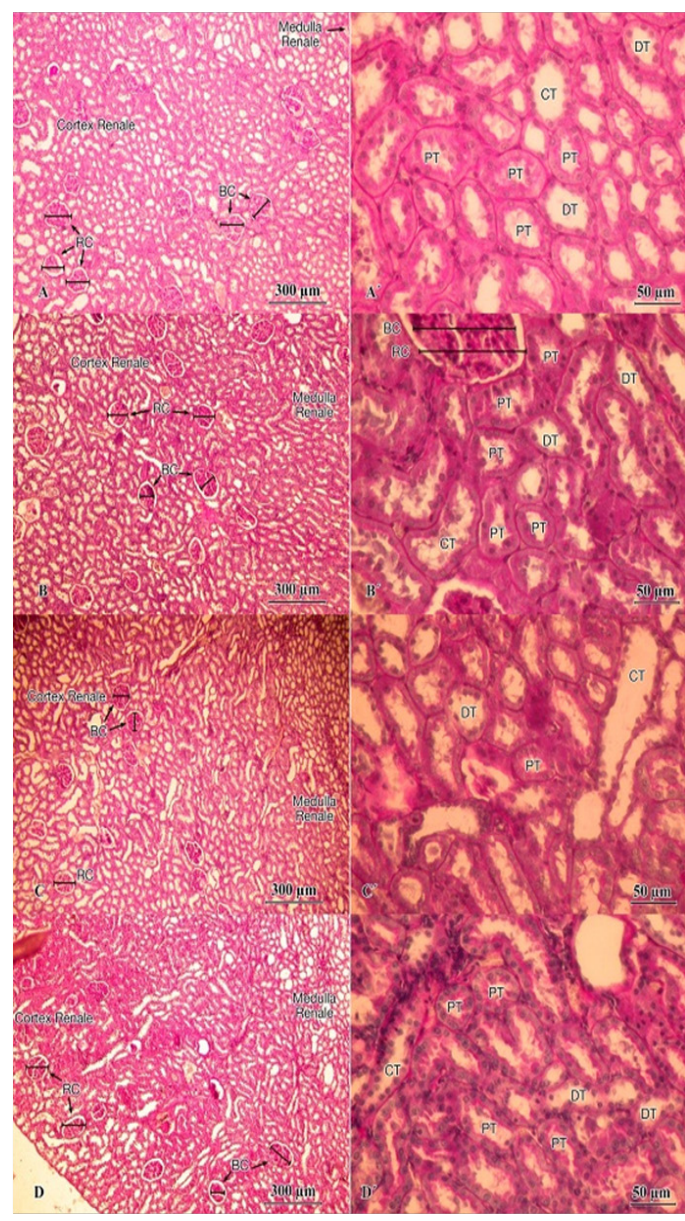

Figure 7. Representative photomicrographs of $5 \mu$ thin renal section with PAS stain. Renal tissue $A$ : Control X4; A': Control X20; B: Smoking X4; B': Smoking X20; C: Smoking+Melatonin X4; C': Smoking+Melatonin X20; D: Smoking+BQ-123 X4; D': Smoking+BQ-123 X20. 
$(p<0.001)$ and Smoking $(p<0.007$ and $p<0.004)$ groups. Total volumes significantly decreased in other groups according to the Control groups (Table 1). Besides, total volumes significantly increased Smoking+Melatonin $(p<0.001)$ and Smoking+BQ-123 $(p<0.001)$ groups according to the Control groups (Table 1 ).

As histo-pathologically, Smoking group according to Control group has observed tubular destruction, cellular cytoplasmic degeneration, and diminished apical membrane microvillus stain with PAS. We observed slight diminishing in the tubular damage in Smoking+Melatonin and Smoking+BQ-123 groups. This diminishing was noticeable in Smoking+BQ-123 group according to Smoking+Melatonin group.

\section{DISCUSSION}

We investigated to the exposed to cigarette smoked rats inquire with regard to the effect of melatonin and ETAR antagonist. We used biochemical analysis in terms of oxidative stress, as well as stereological methods. We found that Melatonin and BQ-123 in the kidneys of rats exposed to smoking cause an increase in the number of the cell with cell proliferation, effects of antioxidant systems in different ways at the end of the 28.day. During smoking, a large number of free radicals and reactive oxygen species are produced $(4,5,32)$. Free radicals to proteins, carbohydrates, lipids, and DNA in cells on are caused oxidative damage (32). Lipid peroxidation was increased by smoking and was decreased by BQ-123 and Melatonin. However, Melatonin decreased its as statistically non-significant (Figure 5). In studies conducted by Ozan et al and Ramesh et al., it was also determined increasing TBARS level with smoking $(33,34)$. The results of antioxidant enzyme activity are probably different depending on the dose and duration of treatment. Renal histologic assessment also shown has a little more recovery with BQ-123. The treatment of Melatonin caused to increase SOD activity and decrease CAT activity even after 28 day is noteworthy. Some researchers found that oral nicotine $(100 \mu \mathrm{g} / \mathrm{ml} /$ day $)$ was administered for 28 days increases ET-1 levels, and decreases SOD activity and $\mathrm{NO}$ level in endothelial cells. Melatonin $(5 \mathrm{mg} / \mathrm{kg} /$ day) bring about decrease ET-1, increase SOD activity and NO level. They suggest Melatonin as a therapeutic intervention for smokers (35). We also found increase SOD activity after use cigarette smoke for 28 day in rats. However we administered i.p. melatonin $25 \mathrm{mg} / \mathrm{kg} /$ day.
Smoking makes with sympathetic activation to the acute effects on the kidneys, causing long-term damage indicates that the vascular endothelial cell damage (36, $37)$. Smoking enhances the level of plasma ET-1 $(15,16)$. It was informed that increased ET-1 level is associated with the harmful effects of smoking such as atherosclerosis (15), essential hypertension (17), cardiovascular pathophysiology (18), renal dysfunction (19). In the chronic renal failure and chronic hemodialysis patient was rise ET-1 level $(38,39)$. There are positive correlation with serum creatinine and ET-1 (19). In addition, the increased level of plasma ET-1 causes the reduction in glomerular filtration rate, urine production renal blood flow (40-42). Therefore, we used ETAR antagonist for inhibiting the harmful effect of cigarette smoking in renal tissue for the first time. Our findings reinforced that ETAR antagonist in smokers might be recovery for the detrimental effects. We thought that the number of renal cell and volume of renal tissue might be increased with response to cellular damage depending on smoking. Melatonin and BQ-123 are known have antioxidant activity should be provoked this response (Table 1). Stereologic analysis is important for submitting a more reliable evaluation because of all tissue sampling. We firstly demonstrated that Melatonin and BQ-123 increase cell number and volume in renal tissue against cellular damage on smoking. In conclusion, the present study demonstrated that cellular depredation of smoke in renal tissue slightly reduced by Melatonin and BQ123 depending on the dose and duration. These agents provoked increase of the cell number of renal tissue in rats. This result was promoted by stereologic analysis with increase of the cell number of renal tissue in rats and histologic staining. Smoking is one of the substantially continuing health problems worldwide. Our findings about orally Melatonin and ETAR antagonist could provide the basis for a therapeutic approach of improving smoking-induced renal damage. These are needed the use of convenient dose and duration.

\section{Conflict of Interest Statement}

The authors declare that there is no conflict of interests. 


\section{Acknowledgement}

This project was supported and approved by The Scientific Research Fund of Gaziosmanpasa University. We would like to thank Dr. Bahadır Ungor for have a significant contribution to this study, but unfortunately he does not survive. We honor him with respect and gratitude.

\section{REFERENCES}

1. Boorjian S. Commentary on "Smoking negatively affects renal cell carcinoma overall and cancer-specific survival." Kroeger N, Klatte T, Birkhauser FD, et al. Institute of Urologic Oncology, David Geffen School of Medicine at the University of California-Los Angeles, Los Angeles, CA: Cancer 2012;118(7):1795-802.

2. Luchetti F, Canonico B, Betti M, Arcangeletti M, Pilolli $F$, Piroddi $M$, et al. Melatonin signaling and cell protection function. FASEB journal: official publication of the Federation of American Societies for Experimental Biology 2010;24(10):3603-24.

3. Huether $G$. Melatonin as an antiaging drug: between facts and fantasy. Gerontology 1996;42(2):87-96.

4. Kinnula VL. Focus on antioxidant enzymes and antioxidant strategies in smoking related airway diseases. Thorax 2005;60(8):693-700.

5. Ozguner F, Koyu A, Cesur G. Active smoking causes oxidative stress and decreases blood melatonin levels. Toxicology and industrial health. 2005;21(1-2):21-6.

6. Tarquini B, Perfetto F, Poli R, Tarquini R. Daytime circulating melatonin levels in smokers. Tumori 1994;80(3):22932.

7. Benigni A, Remuzzi G. Endothelin antagonists. Lancet 1999;353(9147):133-8.

8. Bouallegue A, Daou GB, Srivastava AK. Endothelin-1induced signaling pathways in vascular smooth muscle cells. Current vascular pharmacology 2007;5(1):45-52.

9. Miwa S, Kawanabe Y, Okamoto Y, Masaki T. Ca2+ entry channels involved in endothelin-1-induced contractions of vascular smooth muscle cells. Journal of smooth muscle research $=$ Nihon Heikatsukin Gakkai kikanshi 2005;41(2):61-75.

10. Dhaun N, Goddard J, Kohan DE, Pollock DM, Schiffrin EL, Webb DJ. Role of endothelin-1 in clinical hypertension: 20 years on. Hypertension. 2008;52(3):452-9.

11. Yanagisawa M, Kurihara H, Kimura S, Tomobe $Y$, Kobayashi $M$, Mitsui $Y$, et al. A novel potent vasoconstrictor peptide produced by vascular endothelial cells. Nature 1988;332(6163):411-5.

12. Warren R, Liu G. ZD4054: a specific endothelin A receptor antagonist with promising activity in metastatic castration-resistant prostate cancer. Expert opinion on investigational drugs 2008;17(8):1237-45.

13. Ray A, Hegde LG, Chugh A, Gupta JB. Endothelin-receptor antagonists: current and future perspectives. Drug dis- covery today. 2000;5(10):455-64.

14. Erdogan $H$, Fadillioglu E, Emre MH. Protection from renal ischemia reperfusion injury by an endothelin- $A$ receptor antagonist $B Q-123$ in relation to nitric oxide production. Toxicology 2006;228(2-3):219-28.

15. Haak $T$, Jungmann $E$, Raab $C$, Usadel KH. Elevated endothelin-1 levels after cigarette smoking. Metabolism: clinical and experimental. 1994;43(3):267-9.

16. Goerre S, Staehli C, Shaw S, Luscher TF. Effect of cigarette smoking and nicotine on plasma endothelin-1 levels. Journal of cardiovascular pharmacology. 1995;26 Suppl 3:S236-8.

17. Kosicka T, Kara-Perz H, Perz S. [Evaluation of plasma endothelin-1 concentration in tobacco smoking patients with essential hypertension]. Przeglad lekarski. 2006;63(10):957-9. Epub 2007/02/10. Ocena osoczowego stezenia endoteliny-1 u chorych z nadcisnieniem tetniczym pierwotnym palacych tyton.

18. Rahman MM, Elmi S, Chang TK, Bai N, Sallam NA, Lemos $V S$, et al. Increased vascular contractility in isolated vessels from cigarette smoking rats is mediated by basal endothelin release. Vascular pharmacology 2007;46(1):3542.

19. Hirai $Y$, Adachi $H$, Fujiura $Y$, Hiratsuka A, Enomoto $M$, Imaizumi T. Plasma endothelin-1 level is related to renal function and smoking status but not to blood pressure: an epidemiological study. Journal of hypertension. 2004;22(4):713-8.

20. Irmak MK, Koltuksuz U, Kutlu NO, Yagmurca M, Ozyurt H, Karaman A, et al. The effect of caffeic acid phenethyl ester on ischemia-reperfusion injury in comparison with alpha-tocopherol in rat kidneys. Urological research 2001;29(3):190-3.

21. Lowry $\mathrm{OH}$, Rosebrough NJ, Farr AL, Randall RJ. Protein measurement with the Folin phenol reagent. The Journal of biological chemistry 1951;193(1):265-75.

22. Cortas NK, Wakid NW. Determination of inorganic nitrate in serum and urine by a kinetic cadmium-reduction method. Clinical chemistry 1990;36(8 Pt 1):1440-3.

23. Sun YP, Sears DF, Saltiel J. Principal component self-modeling analysis applied to conformational equilibration of 1,3-butadiene vapor. UV spectra and thermodynamic parameters of the two conformers. Journal of the American Chemical Society 1988;110(18):6277-8.

24. Paglia DE, Valentine WN. Studies on the quantitative and qualitative characterization of erythrocyte glutathione peroxidase. The Journal of laboratory and clinical medicine 1967;70(1):158-69.

25. Esterbauer $H$, Cheeseman KH. Determination of aldehydic lipid peroxidation products: malonaldehyde and 4-hydroxynonenal. Methods in enzymology 1990;186:407-21.

26. Levine RL, Garland D, Oliver CN, Amici A, Climent I, Lenz $A G$, et al. Determination of carbonyl content in oxidatively modified proteins. Methods in enzymology 1990; 186:464-78.

27. Gundersen HJ, Jensen EB. The efficiency of systematic 
sampling in stereology and its prediction. Journal of microscopy 1987; 147(Pt 3):229-63.

28. West MJ, Slomianka L, Gundersen HJ. Unbiased stereological estimation of the total number of neurons in thesubdivisions of the rat hippocampus using the optical fractionator. The Anatomical record 1991;231(4):482-97.

29. Reed MG, Howard CV. Surface-weighted star volume: concept and estimation. Journal of microscopy 1998;190(Pt 3):350-6.

30. Aslan H, Songur A, Tunc AT, Ozen OA, Bas O, Yagmurca M, et al. Effects of formaldehyde exposure on granule cell number and volume of dentate gyrus: a histopathological and stereological study. Brain research 2006;1122(1):191200.

31. Gundersen HJ, Bendtsen TF, Korbo L, Marcussen N, Moller $A$, Nielsen $K$, et al. Some new, simple and efficient stereological methods and their use in pathological research and diagnosis. APMIS : acta pathologica, microbiologica, et immunologica Scandinavica 1988;96(5):379-94.

32. Park EM, Park YM, Gwak YS. Oxidative damage in tissues of rats exposed to cigarette smoke. Free radical biology \& medicine 1998;25(1):79-86.

33. Ozan E, Sonmez MF, Ozan S, Colakoglu N, Yilmaz S, Kuloglu $T$. Effects of melatonin and vitamin C on cigarette smokeinduced damage in the kidney. Toxicology and industrial health 2007;23(8):479-85.

34. Ramesh T, Sureka C, Bhuvana S, Hazeena Begum V. Sesbania grandiflora diminishes oxidative stress and ameliorates antioxidant capacity in liver and kidney of rats exposed to cigarette smoke. Journal of physiology and pharmacology : an official journal of the Polish Physiological Society 2010;61(4):467-76.
35. Rodella LF, Favero G, Rossini C, Foglio E, Reiter RJ, Rezzani $R$. Endothelin-1 as a potential marker of melatonin's therapeutic effects in smoking-induced vasculopathy. Life sciences 2010;87(17-18):558-64.

36. Ritz E, Benck U, Franek E, Keller C, Seyfarth M, Clorius $J$. Effects of smoking on renal hemodynamics in healthy volunteers and in patients with glomerular disease. Journal of the American Society of Nephrology: JASN. 1998;9(10):1798-804.

37. Blann $A D$, McCollum $C N$. Adverse influence of cigarette smoking on the endothelium. Thrombosis and haemostasis. 1993;70(4):707-11.

38. Shichiri M, Hirata Y, Ando K, Emori T, Ohta K, Kimoto S, et al. Plasma endothelin levels in hypertension and chronic renal failure. Hypertension 1990;15(5):493-6.

39. Ottosson-Seeberger A, Ahlborg G, Hemsen A, Lundberg $J M$, Alvestrand A. Hemodynamic effects of endothelin-1 and big endothelin-1 in chronic hemodialysis patients. Journal of the American Society of Nephrology: JASN. 1999;10(5):1037-44.

40. Levin ER. Endothelins. The New England journal of medicine. 1995;333(6):356-63.

41. Hocher B, Thone-Reineke C, Rohmeiss P, Schmager F, Slowinski T, Burst V, et al. Endothelin-1 transgenic mice develop glomerulosclerosis, interstitial fibrosis, and renal cysts but not hypertension. The Journal of clinical investigation 1997;99(6):1380-9.

42. Ortega Mateo A, de Artinano AA. Highlights on endothelins: a review. Pharmacological research : the official journal of the Italian Pharmacological Society 1997;36(5):339-51. 